\title{
SPRAWOZDANIE Z DZIALALNOŚCI WYŻSZEGO SEMINARIUM DUCHOWNEGO W SANDOMIERZU W ROKU AKADEMICKIM 2018/2019
}

Mijający rok akademicki 2018/2019 wspólnota Wyższego Seminarium Duchownego w Sandomierzu przeżywała w łączności z Kościołem w Polsce, obchodząc 30. rocznicę pierwszej wizyty Jana Pawła II w Ojczyźnie. Ponadto ważnym aspektem tego roku była obchodzona w Polsce 80 . rocznica wybuchu II wojny światowej. W omawianym roku akademickim, studia w seminarium podjęło 4 nowych adeptów do kapłaństwa, którzy swoją formację rozpoczęli 1 września 2018 r., poprzez tzw. okres propedeutyczny. Celem tego czasu było: pogłębienie wiary młodych kandydatów, zapoznanie ich z życiem wspólnotowym, jakie panuje w seminarium oraz poznanie różnych zagadnień związanych z życiem i funkcjonowaniem Kościoła powszechnego. W tym okresie udali się oni również na tydzień integracyjny w Bieszczady, do ośrodka Caritas w Nasicznym. Na początku roku sprawozdawczego do kapłaństwa przygotowywało się 42 alumnów. Pierwszy rocznik zasiliło 4 wspomnianych nowych adeptów, na roku drugim studiowało 5 alumnów, na roku trzecim - 10, na czwartym -8 , na piątym -3 oraz na szóstym roczniku było 9 studentów.

\section{Kadra wychowawczo-naukowa}

Pracą formacyjną w minionym roku akademickim kierował Zarząd Seminaryjny, w skład którego wchodzili: rektor - ks. dr Rafał Kułaga, wicerektor - ks. dr Witold Płaza, na stanowisku prefekta posługiwał dyrektor Biblioteki Diecezjalnej ks. dr Piotr Tylec. Nad formacją duchową czuwali ojcowie duchowni: ks. dr Rafał Kobiałka i ks. mgr Szymon Brodowski, który zastąpił na tym stanowisku ks. mgra Mariusza Piotrowskiego. Funkcję dyrektora administracyjnego pełnił ks. mgr Dominik Bucki. Ojców Duchownych w sprawowaniu Sakramentu Pokuty i Pojednania wspierał swoją posługą ks. mgr Marek Kuliński.

Wykładowcami byli: ks. dr Jan Biedroń, ks. mgr Leszek Chamerski, ks. dr Tomasz Cuber, ks. dr Jerzy Dąbek, ks. dr Michał Grochowina, ks. dr Kazimierz Hara, ks. dr Roman Janiec, ks. prof. dr hab. Zdzisław Janiec, ks. dr Krzysztof Kida, ks. dr Rafał Kobiałka s. dr Maria Konopka, ks. dr Adam Kopeć, ks. dr Marek Kozera, ks. dr Bartłomiej Krzos, ks. dr Rafał Kułaga, ks. dr Marek Kumór, ks. dr Paweł Lasek, ks. dr hab. Jacek Łapiński, prof. KUL, ks. dr Jacek Marchewka, mgr Izabela Marciniak, mgr Witold Nowakowski, ks. dr hab. Tomasz Moskal, prof. KUL, ks. dr Waldemar Olech, mgr Agnieszka Pierzchała, ks. dr Witold Płaza, ks. dr Dariusz Sidor, ks. dr hab. Leon Siwecki, prof. KUL, dr Beata Skrzydlewska, ks. prof. dr hab. Bogdan Stanaszek, ks. dr Piotr 
Tylec, ks. mgr Adam Warchoł oraz dr Michał Wyrostkiewicz. Profesorowie prowadzili liczne zajęcia dydaktyczne również poza seminarium, m.in. w Katolickim Uniwersytecie Lubelskim Jana Pawła II w Lublinie oraz Uniwersytecie Papieskim Jana Pawła II w Krakowie. Podejmowali także działalność na rzecz Kurii Biskupiej w Sandomierzu, miejscowego Sądu Biskupiego oraz na licznych odcinkach działalności duszpasterskiej w diecezji sandomierskiej.

\section{Formacja seminaryjna}

\section{Formacja ludzka}

Formacja ludzka realizowana była poprzez indywidualne rozmowy jak również spotkania wychowawców z poszczególnymi rocznikami alumnów oraz z całym alumnatem. Przełożeni dzięki temu chcieli ukształtować w alumnach postawę i osobowość przyszłych kapłanów. Wskazywano więc na potrzebę ciągłej pracy nad sobą celem wypracowania m.in. takich cech osobowości jak: prawość, uczciwość, wzajemny szacunek. Miało temu służyć także podjęcie przez alumnów działalności apostolskiej na terenie Sandomierza i poza nim w czasie różnych wyjazdów związanych z funkcjonowaniem kół apostolatu, m.in. koła misyjnego, Caritas, KSM, harcerstwa, krwiodawstwa, grupy „Pro Life” czy grupy oazowej. Alumni uczestniczyli również w życiu kulturalnym, biorąc udział w sympozjach, spotkaniach, zawodach sportowych i innych tym podobnych wydarzeniach. Natomiast diakoni naszego seminarium opiekowali się kilkoma rodzinami, które potrzebowały codziennej pomocy.

W ramach tej formacji wspólnota seminaryjna przebywała się na wyjeździe integracyjnym w dniach od 2 do 3 maja 2019 r. Alumni wraz z wychowawcami udali się na zwiedzanie Przemyśla i Jasienia oraz na wyprawę górską w Bieszczady. Uczestnicy wyjazdu zakwaterowani byli w ośrodku Caritas w Nasicznym.

\section{Formacja duchowa}

Podstawą tej formacji były codzienne ćwiczenia duchowe w kaplicy seminaryjnej, skoncentrowane wokół Eucharystii oraz indywidualna praca z ojcami duchownymi. W budowaniu duchowości pomagała regularna spowiedź, adoracja Najświętszego Sakramentu, medytacja, lektura duchowa, modlitwa różańcowa czy Koronka do Bożego Miłosierdzia.

W roku akademickim 2018/2019 odbywały się również dni skupienia, które prowadzili: o. Luca Bovio IMC (sekretarz Papieskiej Unii Misyjnej w Polsce), ks. Waldemar Olech, ks. Dariusz Bęc oraz s. Miriam i s. Diana z klasztoru Zgromadzenia Sióstr Matki Bożej Miłosierdzia w Łagiewnikach. Szczególnym czasem dla alumnów były rekolekcje. Jesiennym ćwiczeniom rekolekcyjnym, trwającym od 23 do 27 października 2018 r., przewodniczył ks. Maciej Korczyński. Po tych rekolekcjach ks. bp. dr Edward Frankowski poświęcił strój duchowny 10 alumnom z trzeciego kursu, przyjął do grona kandydatów do święceń diakonatu i prezbiteratu 
2 kleryków z kursu piątego oraz udzielił posługi akolitatu alumnowi z tegoż rocznika. Rekolekcje wielkopostne, które odbyły się w dniach od 3 do 7 marca 2019 r., wygłosił ks. dr Zbigniew Snarski. Oddzielne rekolekcje przeżywali alumni roku piątego przed przyjęciem święceń diakonatu oraz diakoni roku szóstego przed święceniami prezbiteratu. Prowadzili je ojcowie duchowni odpowiedzialni za dany rocznik. Święcenia diakonatu miały miejsce w kościele seminaryjnym pw. św. Michała Archanioła w Sandomierzu w dniu 1 czerwca. Trzech alumnów otrzymało je z rąk ks. bp. dra Edwarda Frankowskiego. Natomiast 19 czerwca święceń kapłańskich w sandomierskiej katedrze udzielił sześciu diakonom bp dr Krzysztof Nitkiewicz, ordynariusz diecezji sandomierskiej.

W roku sprawozdawczym odbyła się również pielgrzymka do miejsc kultu patronów diecezji sandomierskiej - św. Stanisława Kostki i bł. Wincentego Kadłubka, tj. do Krakowa i Jędrzejowa. Miała ona miejsce na rozpoczęcie okresu formacyjnego, w dniu 22 września. Formacji duchowej służył alumnom udział w niektórych celebracjach liturgicznych w sandomierskiej katedrze, m.in.: pierwsza rocznica śmierci bpa seniora diecezji sandomierskiej bpa Wacława Świerzawskiego (7 października 2018 r.), uroczyste zakończenie etapu diecezjalnego procesu beatyfikacyjnego Sługi Bożego ks. Wincentego Granata (9 października), Msza Święta za zmarłych biskupów, kapłanów i osoby konsekrowane (2 listopada), uroczysta Msza Święta z okazji 100. rocznicy odzyskania przez Polskę niepodległości (11 listopada), ustanowienie 20 nadzwyczajnych szafarzy komunii świętej dla diecezji sandomierskiej (24 marca 2019 r.).

Miejscem duchowego formowania alumnów był też kościół seminaryjny pw. św. Michała Archanioła. Wspólnota WSD w Sandomierzu uczestniczyła tam w wielu uroczystych wydarzeniach, m.in.: uroczystości odpustowe ku czci św. Michała Archanioła (29 września 2018 r.), Msza Święta inaugurująca 199. rok akademicki (1 października), Msza Święta za zmarłych rektorów, profesorów, wychowawców, alumnów, siostry zakonne i pracowników świeckich seminarium (3 listopada), Msza Święta ku czci patronki seminarium MB Niepokalanej (8 grudnia), modlitwa o beatyfikację sługi bożego ks. Wincentego Granata (11 grudnia), obchody ku czci św. Tomasza z Akwinu (28 stycznia 2019 r.), udzielenie posług lektoratu dziesięciu alumnom roku trzeciego oraz posługi akolitatu 8 klerykom roku czwartego (7 marca), spotkanie z ministrantami i lektorami diecezji sandomierskiej, podczas którego uroczyście wprowadzono relikwie św. Dominika Savio (9 marca), wielkopostne czuwanie modlitewne młodzieży $\mathrm{w}$ ramach przygotowań do Europejskiego Spotkania Młodych we Wrocławiu, organizowanego przez wspólnotę Taizé (2 kwietnia).

Formacji duchowej kleryków służyły również celebracje liturgiczne poza Sandomierzem: modlitwy o jedność chrześcijan w kościele parafialnym w Rakowie (22 stycznia 2019 r.), święcenia diakonatu alumna Krzysztofa Kozieła w kościele pw. św. Bartłomieja w Staszowie (26 stycznia), Msza Święta Krzyżma w Bazylice Konkatedralnej w Stalowej Woli (18 kwietnia), zakończenie etapu diecezjalne- 
go procesu beatyfikacyjnego Sługi Bożego ks. Stanisława Sudoła w Dzikowcu (2 czerwca) oraz uroczystości pogrzebowe diakona Mateusza Niemca w parafii pw. św. Jana Chrzciciela w Nisku (9 września).

\section{Formacja intelektualna}

Formacja ta była widoczna przede wszystkim przez systematyczną pracę w ramach wykładów oraz ćwiczeń prowadzonych wg ,,ratio studiorum”. Oprócz tego, alumni mieli okazję rozwijać swoje zainteresowania naukowe, biorąc udział w różnych sympozjach, czy to indywidualnie, czy też wraz z całą wspólnotą. Ponadto program studiów w WSD w Sandomierzu obejmuje liczne wykłady, ćwiczenia i konwersatoria, które weryfikują kolokwia, zaliczenia i egzaminy. Alumni przygotowują się do tych prac podczas studium indywidualnego, które wpisane jest w program dnia. Wszyscy alumni uczęszczają na zajęcia z języka angielskiego. Dodatkowo prowadzone są lektoraty z języków: włoskiego i francuskiego oraz języka migowego. Zwieńczeniem formacji naukowej w ramach studiów teologiczno-filozoficznych była obrona prac magisterskich diakonów. Dnia 6 czerwca 2018 r., siedmiu diakonów pozytywnie przedstawiło swoje prace magisterskie w Katolickim Uniwersytecie Lubelskim, wieńcząc tym swoje studia w naszym domu formacyjno-dydaktycznym. Przed obroną zdali oni egzaminy absolutoryjne z Pisma Świętego, teologii dogmatycznej, teologii moralnej oraz prawa kanonicznego. Ponadto alumni piątego roku i diakoni z rocznika szóstego w ramach praktyk katechetycznych prowadzili katechezy w szkołach Sandomierza. Dodatkowo alumni, pisząc i redagując artykuły, wydali 2 numery czasopisma „Powołanie”, tym samym rozwijając swoje zdolności i talenty.

W ramach formacji intelektualnej w roku akademickim 2018/2019 miały miejsce następujące wydarzenia: spotkanie z bpem Georgiem Cosmasem, przewodniczącym Konferencji Episkopatu Zambii (30 września 2018 r.), sympozjum z okazji 200-lecia diecezji sandomierskiej poświęcone wyzwaniom duszpasterskim (20 października), promocja książki ks. dr hab. Tomasza Moskala, prof. KUL, o członkach Kapituły Katedralnej w Sandomierzu (15 listopada), akademia ku czci św. Tomasza z Akwinu, podczas której ks. dr hab. Marek Tatar, prof. UKSW wygłosił referat „Rozum wobec wiary - współczesna pokusa gnostycyzmu" (28 stycznia 2019 r.), promocja albumu Mariana Grzybowskiego „Ziemia mówiąca Bogu tak” oraz książki z pełnym tekstem libretta „Oratorium o Męczennikach Sandomierskich” autorstwa ks. Krzysztofa Lechowicza (21 marca).

\section{Formacja duszpasterska}

Formacja duszpasterska widoczna była na wielu płaszczyznach, zarówno podczas trwania roku akademickiego jak i w czasie praktyk wakacyjnych, czy przerw 
świątecznych. Podobnie jak w latach ubiegłych alumni na wakacjach w ramach formacji duszpasterskiej pełnili liczne posługi: po pierwszym i drugim roku pracowali jako przewodnicy w bazylice katedralnej, kościele seminaryjnym oraz Muzeum Diecezjalnym w Sandomierzu, po roku trzecim - byli animatorami podczas rekolekcji oazowych, po roku czwartym - brali udział w obozach organizowanych przez Caritas Diecezji Sandomierskiej, po roku piątym - uczestniczyli w Pieszej Pielgrzymce Ziemi Sandomierskiej na Jasną Górę.

Ważną inicjatywą dla wspólnoty seminaryjnej były rekolekcje dla młodzieży męskiej. Miały one miejsce w dniach od 30 listopada do 2 grudnia 2018 r. Ponadto, alumni piątego roku i diakoni szóstego roku spotykali się podczas pierwszej i drugiej serii katechez powołaniowych z młodzieżą maturalną szkół na terenie diecezji sandomierskiej. Formą działalności duszpasterskiej były również wizyty alumnów w parafiach naszej diecezji w ramach kwesty cmentarnej (1 listopada) oraz podczas wyjazdów powołaniowych. Pogłębianiu więzi z wiernymi służyły także: Wieczór Cecyliański i spotkania opłatkowe z członkami Parafialnych Kół Przyjaciół Wyższego Seminarium Duchownego w Sandomierzu.

Alumni przygotowywali liczne akademie i przedstawienia, które prezentowali dla szerszego grona odbiorców, m.in. klerycy z rocznika drugiego przygotowali przedstawienie z okazji dnia św. Mikołaja (6 grudnia 2018 r.), a alumni z roku trzeciego przygotowali „Quiz” z okazji Święta Niepodległości.

W minionym roku akademickim w ramach czynnego apostolatu, alumni podejmowali również posługę w kaplicy Domu Opieki Społecznej w Sandomierzu, a także byli szafarzami Najświętszego Sakramentu w sandomierskim szpitalu. Poza tym, odwiedzali chorych w domach, kapłanów mieszkających w Domu Księży Emerytów, czynnie udzielali się podczas praktyk w Domu Pomocy Środowiskowej w Sandomierzu, brali udział w ramach praktyk w ośrodku „Radość życia” prowadzonym przez Caritas Diecezji Sandomierskiej.

Zwyczajną formą praktyki duszpasterskiej była codzienna posługa alumnów w kościele seminaryjnym. Alumni mogli sprawdzić swoje umiejętności i nabyć nowe doświadczenia przez posługę kaznodziejską. W ramach praktyk alumni z piątego rocznika głosili próbne kazania w kościele św. Michała Archanioła, natomiast diakoni wygłaszali kazania w czasie dyżuru wakacyjnego.

Ważne miejsce we wspólnocie WSD w Sandomierzu pełni chór klerycki, który uświetniał swoją obecnością liczne spotkania i uroczystości. Chór działał pod batutą ks. mgra Leszka Chamerskiego.

W dniu 1 maja bramy naszej Alma Mater zostały otwarte dla przyjaciół i sympatyków Seminarium. Nasze seminarium odwiedziło wówczas kilka tysięcy osób. Takie spotkania były dla alumnów doskonałą okazją do sprawdzenia w praktyce swoich umiejętności nawiązywania kontaktu z wiernymi oraz lekcją organizacji tego typu inicjatyw w przyszłości. 


\section{Sprawy administracyjno-gospodarcze}

Budynek Wyższego Seminarium Duchownego należy do wyróżniających się zabytków, sięga swymi początkami XVII w. Wspólnota seminaryjna dokładała wszelkich starań, aby jej dom utrzymany był w należytym stanie. W czasie minionego roku akademickiego wykonano izolację pionową skrzydła północnego. Kontynuowano również prace konserwatorskie w kościele pw. św. Michała Archanioła (m.in. odnowienie zabytkowej ambony). Podjęto również renowację figury Jezusa Dobrego Pasterza, usytuowanej na seminaryjnym wirydarzu, co ma być zewnętrznym znakiem zbliżającego się jubileuszu 200-lecia WSD w Sandomierzu. Ponadto wykonywano prace bieżące konieczne dla funkcjonowania budynku.

Za możliwość realizacji prac na tylu odcinkach życia seminaryjnego dziękujemy najpierw Panu Bogu a następnie ludziom. Pragniemy, by prace te zostały dobrze wykorzystane na większą chwałę Stwórcy i dla zbawienia ludzi, jak również ku ciągłemu budowaniu jedności tych, którzy tutaj mieszkają.

Ks. Rafał Kułaga

Rektor WSD w Sandomierzu 